\title{
POSSIBILITY OF LEUKOGENICITY EFFECT OF LONG TERM USE OF HYDROXYUREA IN SICKLE CELL ANAEMIA
}

Archana Singh ${ }^{1}$, Bhanu P. Singh ${ }^{2}$

\section{HOW TO CITE THIS ARTICLE:}

Archana Singh, Bhanu P. Singh. "Possibility of Leukogenicity Effect of Long Term Use of Hydroxyurea in Sickle Cell Anaemia". Journal of Evolution of Medical and Dental Sciences 2015; Vol. 4, Issue 52, June 29;

Page: 9103-9107, DOI: 10.14260/jemds/2015/1319

ABSTRACT: Malignancy in patient with Sickle Cell Anemia has been reported by many researchers, but the type of malignancy and its incidence remain undefined. Before this case report; the association of chronic myeloid leukemia in sickle cell patients, 5 cases were reported in 2005, 9 cases reported in 2008 and then 10 cases in the year of 2011. Hydroxyurea is an antimetabolite that minimizes pain and prolongs survival in patient with Sickle Cell Anemia. This drug is more widely prescribe in sickle Cell anemia patients in Chhattisgarh State where such disease have high prevalent. Leukemogenic risk of Hydroxyurea is extrapolated from its reported risk in myeloproliferative disorders. Long term studies on effect of Hydroxyurea in Sickle Cell Disease children have been reported by many researchers. In this case leukemia may be related with long term use of Hydroxyurea but for accurate interpretation of future reports of malignancy in patient with Sickle Cell Disease, especially those receiving Hydroxyurea must be monitored.

KEYWORDS: SCA, CML, HU.

INTRODUCTION: Hydroxyurea is an antimetabolite that minimizes pain and prolongs survival in patients with sickle cell anemia.(1) Sickle cell disease (SCD) is one of the most common genetic diseases in Chhattisgarh, India. Most patients suffer intermittent pain crises and life-threatening events while life expectancy is considerably reduced. Until the last decade management was purely preventative or supportive aimed at symptom control. Apart from stem cell transplant, there is no cure but the oral chemotherapeutic drug Hydroxyurea (HU) has now established a role in ameliorating the disease and improving life expectancy for most patients. There are side effects and risks of HU treatment in SCD but for moderate and severely affected patients, the benefits can be significant. It is very widely prescribe by the physician treating the sickle cell anemia just to reduce the episode of sickle cell crisis by increasing the fetal hemoglobin.(2) Leukemogenic risk of Hydroxyurea is extrapolated from its reported risk in myeloproliferative disorders. ${ }^{(3)}$ Hematologic Malignancies in patient with sickle cell anemia are rare. Very few cases have been reported worldwide. The awareness and possibility of sickle cell anemia and coexisting malignancies have undergone tremendous changes. Reported malignancies with sickle cell anemia patients are acute lymphoblastic leukemia, chronic granulocytic leukemia, multiple myeloma malignant histiocytosis, non-Hodgkin`s lymphoma, Cutaneous T cell lymphoma and chronic lymphocytic.(4) This is the first case report on sickle cell anemia with chronic granulocytic leukemia which comes to our knowledge in the region of Chhattisgarh.

CASE HISTORY: A 30 years old female a known case of Sickle cell anemia was admitted in medical ward, complaining of huge lump in abdomen with 6 month history of low grade fever, fatigue, night sweats. She had remarkable pain in abdomen \& left hypochrondium for 4 month. She had past history 


\section{REVIEW ARTICLE}

of vaso-occlusive crisis. She received approximately 10 unit of whole blood transfusion during last 2 year. She was under medication of Hydroxyurea for more than 15 years the treatment of her disease. Her physical examination revealed huge spleenomegaly mild hepatomegaly, bilateral axillary lymphadenpathy, Pallor and mild jaundice. Complete blood count through five part Hematology Analyzer Pentra-60 (Horiba-ABX, Span) showed Hemoglobin 7.8Gm/dl and high leukocyte count 82,000/cu mm, Hematcrit 28.8\%, MCV 88/ fl, MCH 23.7 pg, MCHC 26.9g/dl, platelets 373000/ $\mu \mathrm{L}$.

When the patient's leukocyte count was elevated and was found positive for sickle cell test by Sodium Meta bisulphate oxygen reduction test, then the patient was examined and investigated in detail. Spleen was enlarged up to pelvis and liver was enlarged up to costal margin in Sonography. Liver enzymes were elevated. High Performance Liquid Chromatography (HPLC) conducted through D-10 (Biored, USA) for hemoglobin shows Sickle Hemoglobin 30.4\%, Fetal hemoglobin $<0.8 \%$ Hb A1 C 4.8\% and Hb A2 4.2\%, Peripheral Blood picture showed marked red cell anisopoikilocytosis, drepanocytes, with fare number of Narmoblasts (7NRBC/100 RBC).

White Blood cell series presented with fair number of Metamyelocytes 17\% Promyelocytes 07\% and Band cells 14\%, Myeloblasts 04\%, Myelocytes 11\%, Basophils 12\% Monocytes 20\%, Lymphocytes 09\% and mature Neutrophils $06 \%$. Bone Marrow aspiration \& examination revealed depressed erythropoiesis, leukocytes hyperplasia with shift to left predominantly Promyelocytes, Metamyelocytes and Myeloblasts promption diagnosis of chronic Myeloid leukaemia.Cytological evaluation of peripheral blood sample confirmed a Karyotype of 46 XX T (9,22) (q 34;q 11.2); confirming the diagnosis of chronic Myelogenous leukemia.

DISCUSSION: The development of malignancy in persons with Sickle cell anemia has been documented by various researches.(5-15) Hodgkin`s lymphoma as first hematologic malignancy reported neoplasm in sickle cell disease in 1938.(5) Frequency of different hematologic malignancy since 1960 in sickle cell disease patients reported in 1998.(16) Hydroxyurea has been used for since so long for management of Sickle cell Anemia to reduce the number of painful episodes.(17) Long term safety of the drug, in particular of its Leukemogenic potential is still questionable. Leukemia has been reported in myeloblastic syndrome after at least 3-4 years of exposure of to the drug.(17-18) Long term studies on effect of Hydroxyurea in Sickle Cell Disease children has been reported by many researchers. ${ }^{(19-20)}$

Before this case report, highlighting the association of chronic myeloid leukemia in sickle cell patients, 5 cases were reported in 2005(21) 9 cases reported in 2008 and then 10 cases in the year of 2011.(22) 2 cases were found in combination of Sickle/ $\beta 0$ Thallassamia with Chronic myeloid leukemia.(4)

The possible explanation for the rarity of hematologic malignancy such as Chronic Myeloid Leukemia, present in sickle cell anemia is the short life expectancy of these patients. With modern medical care, the average life expectancy of sickle cell disease patients has improved in both the genders, therefore more hematologic malignancy along with other complications are expected to be observed in elderly patients with sickle cell anemia(21) In present reported case Chronic Myeloid Leukemia with Sickle Cell Disease is at the age of 30 years. Ferster et al refer to a malignancy in one SCD on Hydroxyurea.(23) A case of leukemia with background of cells suggesting mylodysplastia was reported in a 27 years old SCD patient on Hydroxyurea treatment for 8 years. ${ }^{24)}$

Many sickle cell disease patients have been managed effectively with Hydroxyurea for several years with no report termination into neoplastic condition. In present case report patient had 
received Hydroxyurea for the period of 15 years \& had received multiple blood transfusions the duration of 2 years.

Hydroxyurea reduce d NTP pools, thereby interfering with both DNA synthesis and repair mechanism.(22) In vivo, hydroxyl urea prevents complete repair of DNA damage, leading to accumulation of somatic mutation and chromosomal damage. In vivo Hydroxyurea therapy has been suggested to increase the risk of acute leukemia for the patient with Myeloproliferative disorder $(18,25)$ but its carcinogenic potential in other clinical settings is much less compelling and no adults up to 9 years of drug exposure have had secondary leukemia develop(26) Moreover, quantative analysis of acquired DNA mutations suggest that mutagenic potential hydroxyl urea for patient with Sickle Cell Disease is low(27) however, anecdotes of Malignancy or Myelodysplasias in patient with Sickle Cell Disease on Hydroxyurea are emerging $(24,28)$ consideration of its carcinogenic potential should be given, because more and more sickle cell anemia may be treated with Hydroxyurea and pathology should be altered to this potential.

Special risk factors related to malignancy formation in Sickle Cell Disease have been proposed which include infection (e.g. human immunodeficiency virus or hepatitis C), transfusion-related immune-modulation, and persistent cellular and organ damage induced by stimulation of inflammatory cells due to Vaso-Occlusive phenomenon leading to granulocytic cell differentiation and Chronic Myeloid Leukemia and exposure to bone marrow transplantation or modern chemotherapy such as Hydroxyurea. $(4,29)$

The leukocytosis with depressed erythropoiesis picture, in peripheral blood as considered as secondary reaction to sever anemia, infection or other stresses that commonly occur in patient with sickle cell anemia. As demonstrated in this case Chronic myeloid leukemia should be included in differential diagnosis in patient with sickle cell anemia with hepato-spleenomegaly and also advent of Hydroxyurea therapy, immune-modulation, viral infection, stem cell transplantation through multiple blood transfusion to be put in consideration for emergening cases of Chronic myeloid leukemia in Sickle Cell Disease. In this case leukemia may be related with long term use of Hydroxyurea. Data presented with different researchers are very less but possibility of malignant potential of Hydroxyurea cannot be ignored. For accurate interpretation of future reports of malignancy in patient with Sickle Cell Disease, especially those receiving Hydroxyurea must be monitored.

\section{REFERENCES:}

1. Steinberg MH, McCarthy WF, Castro O, Ballas SK, Armstrong FD, Smith W, et al. Investigators of the Multicenter Study of Hydroxyurea in Sickle Cell Anemia and MSH Patients' Follow-Up. The risks and benefits of long-term use of hydroxyurea in sickle cell anemia: A 17.5 year follow-up. Am J Hematol.2010; 85: 403-408.

2. Devies SC, Gilmore A. Role of Hydroxyurea in treatment of SCD; Blood Rev 2003 June; 17(2): 99109.

3. Kiladjian JJ, Rain JD, Bernard JF, Briere J, Chomienne C, Fenaux P. Long-term incidence of hematological evolution in three French prospective studies of hydroxyurea and pipobroman in polycythemia vera and essential thrombocythemia. Semin Thromb Hemost. 2006; 32: 417-421.

4. Sallam MM, Alsuliman AM, alahmed HE, Alabdulaali MK. Chronic myelogenous leukemia in sickle cell/beta0-thalassemia. Indian J Pathol Microbiol 2011; 54: 597-598.

5. Kato k, Cardozo WW. Hodgkin`s disease with terminal eosinophelia occurring in a negro child with sicklemia. J Pediatr 1938; 12: 165-175. 
6. Goldin AG, Kelty KC, Beard MF. Sickle cell anemia terminating in acute myeloblastic leukemia. Ann Intern Med 1953; 920-926.

7. Jeckson RE, Short BJ. Frequency and prognosis of coexisting sickle cell disease and acute leukemia in children. Chin Pediatr 1972; 11: 183-185.

8. Nowell PC, Jensen J, Gardner F. Two complex transpocations in chronic granulocytic leukemia involving chromosomes 22, 9, and a third chromosome. Hum Genet 1975; 530: 13-21.

9. Papayannopoulou T, Bunn HF, Stamatoyannopoulos G. Cellular distribution of hemoglobin $\mathrm{f}$ in a clonal hemopoietic stem - cell disorder. New England journal of Medicine 1978; 298: 72-75.

10. Samal GC. Sickle cell anemia with acute myeloid leukemia. A case report. Indian Pediatr 1979; 453-454.

11. Sarma PSA, Chawal BK, Das SR. Chronic myeloid leukemia is a patient with sickle cell anemia. J Assoc Physcians India 1986; 821-822.

12. Stricker RB, Linker CA, Crowley TJ, Embury SH. Hematologic malignancy in sickle cell disease: Report of four cases and review of the literature. Am J Hematol 1986; 21: 223-30.

13. Li JC, Kaminskas E. Progressive formation of DNA lesion in cultures Ehrich ascetic tumor cells treated with hydroxyl urea. Cancer Res 1987; 47: 2755-2788.

14. Phillips J G, Hartman J, Kinney TR, Sokal JE, Kaufman RE. Chronic granulocytic leukemia in a patient with sickle cell anemia. Americal Journal of Medicine; 1988; 85: 567-569.

15. Rosner F, Grumwald HW. Chronic granulocytic leukemia in a patient with hemoglobin SC disease. Americal Journal of Hematology 1989; 31: 302.

16. Kim HS, Yospur L, Niihara Y; Chronic lymphocytic leukemia in a patient with sickle cell anemia. West J Med 1998; 169: 114-116.

17. Mariane de Montalembert and Sally C. Devies; Blood, 1 November 2001.Vol 98, No9, pp.28782879.

18. Najeen Y, Rain JD. For French polycythemia study group. Treatment of polycythemia vera: use of $32 \mathrm{P}$ alone or with a maintenance therapy using Hydroxyurea in 461 patients aged more than 65 years. Blood 1997; 89: 2319-2327.

19. Kinney TR et al; Safty of Hydroxyurea in children with SCA: Result of HUG-KIDS study, a phase trial I/II. Blood 1999; 94: 1550-1554.

20. De Montalembert M et al Preliminary report of a toxity study of Hydroxyurea in SCD;Arch Dis Child.1999; 81: 437-439.

21. Chen L, Zhuang M, Shah HQ Lin JH. Chronic myelogenous leukemia in sickle cell anemia. Arch Pathol Lab Med 2005; 129: 423-24.

22. Schultz WH Were RE. Malignancy in patients with sickle cell disease. Am J Hematol 2003; 74: 249-53.

23. Ferster A et al. Five years of experience with Hydroxyurea in children and young adults with SCD.Blood 2001; 97: 3628-3632.

24. Rauch A et al; Leukemogenesis of Hydroxyurea in the treatment of SCA. Blood 1999; 94: 415a.

25. Najeen Y, Rain JD. For French polycythemia study group. Treatment of polycythemia Vera: The use of Hydroxyurea and pipobroman in 292 patients under the age of 65 years. Blood 1997; 90: 3370-3377.

26. Steinberg MH, Barton F, Castro 0, et al, Effect of Hydroxyurea 9 on mortality and morbity in adult sickle cell anemia: risk and Benefits up to 9 years of treatment. JAMA 2003; 289: 16451651. 


\section{REVIEW ARTICLE}

27. Hanft VN, Fruchtman SR, Pickens CV, Rosse WF, Howard TA, Were RE. Acquired DNA mutation associated with in vitro and vivo Hydroxyurea exposure. Blood 2000; 95: 3589-3593.

28. Moschovi M Psychou F, Memegas D, Tsangaris GT, Tzirtzatiy-Stathopoulou F, Nikolaidou P. Hodgkin`s disease in a child with sickle cell disease treated with hydroxyl urea. Pediatr Hematol Oncol 2001; 19: 371-376.

29. Chen L, Zhuang M, Shah HQ Lin JH. Chronic myelogenous leukemia in sickle cell anemia. Arch Pathol Lab Med 2005; 129: 423-24.

\section{AUTHORS:}

1. Archana Singh

2. Bhanu P. Singh

\section{PARTICULARS OF CONTRIBUTORS:}

1. Associate Professor, Department of Radio-diagnosis, Chhattisgarh Institute of Medical Sciences, Bilaspur, Chhattisgarh.

2. Associate Professor, Department of Pathology, Chhattisgarh Institute of Medical Sciences, Bilaspur, Chhattisgarh.

FINANCIAL OR OTHER COMPETING INTERESTS: None

\section{NAME ADDRESS EMAIL ID OF THE CORRESPONDING AUTHOR:}

Dr. Archana Singh, H-2/150,

Narmada Nagar,

Bilaspur-495001,

Chhattisgarh.

E-mail: radiodiagnosiscimsbilaspur@gmail.com bloodbankcimsbilaspur@gmail.com

Date of Submission: 18/06/2015. Date of Peer Review: 19/06/2015. Date of Acceptance: 20/06/2015. Date of Publishing: 26/06/2015. 